ORIGINAL ARTICLE

\title{
Preventive Practice and Associated Factors towards COVID-19 among College Students in Amhara Region, Ethiopia: A Cross- Sectional Study
}

\author{
Abay Woday Tadesse ${ }^{1,2^{*}}$, Negesse Melese Abebe $^{2}$, Sisay Eshete Tadesse ${ }^{3}$, \\ Mulugeta Chanie Wube ${ }^{4,2}$, Ahmed Ali Abate ${ }^{2}$
}

\section{OPEN ACCESS}

Citation: Abay Woday Tadesse, Negesse Melese Abebe, Sisay Eshete Tadesse, Mulugeta Chanie Wube, Ahmed Ali Abate. Preventive Practice and Associated Factors towards COVID-19 among College Students in Amhara Region, Ethiopia: A Cross-Sectional Study. Ethiop J Health Sci. 2021;31(1):3. doi:http://dx.doi.org/ 10.4314/ejhs.v31i1.2 Received: August 4, 2020

Accepted: September 2020

Published: January 1, 2020

Copyright: (C) 2021 Abay Woday Tadesse, et al. This is an open access article distributed under the terms of the Creative Commons Attribution License, which permits unrestricted use, distribution, and reproduction in any medium, provided the original author and source are credited. Funding: Nil

Competing Interests: The authors declare that this manuscript was approved by all authors in its form and that no competing interest exists.

Affiliation and Correspondence:

${ }^{1}$ Samara University, College of Medicine and Health Sciences, Afar Region, Samara, Ethiopia ${ }^{2}$ Dream Science and Technology College, Amhara Region, Dessie, Ethiopia ${ }^{3}$ College of Health Science, Debre Markos University, Debre Markos, Ethiopia ${ }^{3}$ Wollo University, College of Medicine and Health Sciences, Amhara Region, Ethiopia ${ }^{4}$ Wollo University, College of Business and Economics, Amhara Region, Ethiopia

*Email: abaywoday@yahoo.com, abaywonday@su.edu.et

\section{ABSTRACT}

BACKGROUND: Ethiopia has taken unprecedented preventive measures like closure of higher education institutions to halt the spread of COVID-19. However, still, there is scarce information regarding the knowledge, attitude, and practice (KAP) of students towards COVID-19 pandemic. Thus, this study aimed to assess the KAP and associated factors of preventive measures against COVID19 among students.

METHODS: A cross-sectional study was conducted on 422 students. The sample was proportionally allocated into the randomly selected four colleges, and the students were recruited using a systematic random sampling technique.Variables with pvalue $<0.25$ in the bivariate logistic regression analysis were entered into the multivariable logistic regression model.

RESULTS: This study involved 408 students with response rate of 96.6\%. The levels of good knowledge, positive attitude and good practice towards COVID-19 were 69.6\%, 56.6\% and $65 \%$ respectively. After adjusting for covariates, being in the late adolescent age group (16-20), living with $>5$ family size, and being single were predictors of knowledge level. Besides, being single, attending diploma (TVET) level trainings, and being year-two students were predictors of attitude levels. Similarly, urban residence, being regular students, and being year-one students were the independent predictors of practice level of students.

CONCLUSION: In this study, only two-third of the students had good preventive practice level towards COVID-19, which is below the Organization's recommendation. Thus, the national, regional and local governments should develop effective and inclusive prevention strategies to address students who are at home due to COVID-19 pandemic.

KEYWORDS: COVID-19, Knowledge, Attitude, Practice, Students, Amhara Region, Ethiopia

\section{INTRODUCTION}

Coronavirus Disease (COVID-19) is a viral disease caused by the beta coronavirus called severe acute respiratory syndrome coronavirus2 (SARS-CoV-2) (1, 2). Corona Virus Disease-2019 (“COVID-19”) was first detected in December 2019 in Wuhan, China (3). Since COVID-19 has been declared a global pandemic by the World Health 
Organization (WHO), it has made a rapid spread across the world and it is causing high mortality and morbidity $(1,4)$.

Globally, it causes an estimated number of 5.8 million cased and nearly half a million deaths at the end of May 2020 (5). In Ethiopia, according to the Ethiopian public health institute situational report, COVID-19 causes 5,846 cased and 103 death by the end of May, $2020(6,7)$. Similarly, in Amhara Region, there were 307 cases and 5 death, which is the setting for this study.

Following this pandemic, nations across the globe have taken different preventive measures. These include movement restriction, confinement to home, and closure of schools and other social services (8-10). Hence, appropriate knowledge, attitude, and practices toward the preventive measures are mandatory to halt the spread of the COVID-19 outbreak in countries (11-14). However, previous studies revealed that communities have shown poor knowledge and negative attitude towards the preventive measures of COVID pandemic (15-17). On the other hand, most of the previous studies were predominately focused on the knowledge, attitude, and practices of health care workers toward the preventive measures of COVID-19 (18-20) that was not represent the KAP of college students.

Ethiopia has taken different prevention and control measures to halt the spread of COVID-19. These include school closure, stay at home, keep social and physical distances, putting hand washing basins in places where people use in common (banks, churches/mosques, markets), and establishment of state of emergency at the national level $(21,22)$.

A study conducted in China revealed that adherence to prevention and control measures is an essential strategy to halt the spread of the outbreak, which is directly linked to the knowledge, attitudes, and practices (KAP) level of the population towards COVID-19 (23). In fact, the researchers were interested to assess the KAP of undergraduate students towards COVID-19. Besides, conducting survey studies may be helpful to generate rapid information regarding the KAP level of students towards COVID-19 who are at home due to the pandemic. Moreover, limited studies have been conducted to date to address the practice of students towards the prevention measures of COVID 19 in the country.
Therefore, this study was intended to assess the preventive practice and associated factors towards COVID-19 among college/university students.

\section{METHODS AND MATERIALS}

Study setting and participants: A communitybased cross-sectional study was conducted from May 15-25, 2020 to assess knowledge, attitude, and practice level of students towards COVID-19. The study was conducted among students who were learning in the four randomly selected private and public colleges and universities namely; Dream Science and Technology College, Dandi Boru College, Unity University, and Dessie Health Science College. These higher institutions are found in South Wollo Zone, administration Dessie city. Dessie city administration is located $401 \mathrm{Km}$ away from the capital city of Ethiopia, Addis Ababa. The city has eight private colleges, one private university, and three public colleges which accommodate a total of 23,507 students in different fields of study.

All active students, registered in the secondsemester academic calendar, and students of 16 and above years of age were included in this study. However, students who were seriously ill during the data collection period were not included in this study. The sample size was determined using a single population proportion formula with assumptions: 5\% type I error, 95\% Confidence intervals, $50 \%$ proportion for either knowledge, attitude, practice level since no study was one in Ethiopia prior to this study. Finally, the researchers added $10 \%$ to compensate for the nonresponse of participants and the final sample size became 422.

A simple lottery method was applied to select the higher education institutions. Proportional sample allocation was employed to get the required sample size from each selected university/colleges. And, then systematic random sampling technique was employed to get the study participants with their phone numbers from each teaching institution's registrar offices.

From the twelve colleges and universities found in Dessie city administration, three colleges and one university were randomly selected.The calculated sample size was proportionally allocated in each college based on the secondsemester academic student number reports. To 
calculate the required number of participants from each college, we multiplied the total number of students actively learning in each college by the sampling fraction $(\mathrm{n} / \mathrm{N})$. The sampling fraction is approximately equal to six for all colleges. Accordingly, every $6^{\text {th }}$ participant was selected using systematic random sampling technique from each college registrar's office log-book.

Dependent variable were the preventive practice (good/poor) towards COVID-19 while independent variables were sociodemographic characteristics (age, residence, sex, marital status, religion, enrollment type, program, academic year, field of study, pocket income, family size), knowledge (good/poor), attitude (positive/negative), towards the preventive measures of COVID-19.

Data collection tools and procedures: The questionnaire was adapted from studies conducted before this study (24-26) and modified into context. The questionnaire was developed in English language. It has two main parts: sociodemographic and KAP related questions. The sociodemographic related variables consist of age, residence, sex, marital status, religion, enrollment type, program, academic year, field of study, average monthly pocket income, and family size. The second part of the survey assessed knowledge, attitude, and practice of students about COVID-19, which consists of nine items for knowledge, eleven items for attitude and eleven items for practice level (Supp. File 1). In the KAP questions with three options (Yes, No, and "I don't know"), correct responses were given one point while incorrect responses or "I do not know" responses were given zero points. Similarly, 'moderate' and 'high' were given one point while 'very low' and 'low' were given zero points.

The questionnaire was translated into the local language (Amharic) and back to English to keep its consistency. The data collection tool was pretested on $5 \%$ (21 participants) of the students who were learning in other than selected colleges (i.e. students from Yeju college located in Woldia town) and some amendments were made based on the pretest findings. The data was collected using both phone-call and personal interviews. Phonecall was used for students who are out of Dessie town. Trained health professionals who were working out of the selected colleges approached the study participants.
Data management and analysis: The data were cleaned, coded and entered into Epi data version 3.1 software and exported to SPSS version 24.0 for analysis. The descriptive analysis was done and the results were presented using texts, frequency tables, figures and median with Interquartile range.

Bivariate logistic regression analysis was done to assess the association between KAP and each independent variable. The socio-demographic factors with knowledge, attitude, and practice of preventive measures against COVID-19 were the included factors in the bivariate analysis. The independent variables with $p$-value less than 0.25 were considered in the final model. Correlation between independent variables was assessed but we did not find any correlation between independent variables. The model fitness was also checked using Hosmer-Lemeshow model fitness test. Finally, multivariable logistic regression analysis was done with backward elimination methods to control potential confounders and to identify the factors associated with the KAP of students towards COVID-19. A statistical significance level was declared at a P-value of less than 0.05 .

The following operational definition are used in this study.

Knowledge level: students who correctly answered $70 \%$ or more of the knowledge questions were considered as students with good knowledge level while students who answered correctly below $70 \%$ of the knowledge questions were considered as having poor knowledge.

Attitude level: Students who correctly answered $70 \%$ or more of the attitude questions were considered as students with apositive attitude while students who correctly answered below $70 \%$ of the attitude questions were considered as students with a negative attitude.

Practice level: Students who correctly answered $70 \%$ or more of the practice questions were considered as students with good practice level while students who correctly answered below 70\% of the practice questions were considered as students with poor practice.

\section{RESULTS}

Characteristics of participants: In this study, 408 participants were involved with a response rate of $96.6 \%$. The median age of the participants 
was 21 years with three Interquartile Range (IQR). Of the total students, $155(38.0 \%)$ lived in the rural residence, 194(47.5\%) were females, 215(52.7\%) were learning TVET or diploma level training and
$340(83.3 \%)$ were living with their families during the COVID-19 lockdown. In this study, the participants had a median of 5 total family size with 3 IQR (Table 1).

Table 1: Sociodemographic characters of college students in Amhara Region, Ethiopia, 2020

\begin{tabular}{|c|c|c|c|}
\hline List of Predictors & Category of variables & Frequency $(n=408)$ & Percentage (\%) \\
\hline \multirow[t]{2}{*}{ Age of participants (in years) } & $16-20$ & 166 & 40.7 \\
\hline & $>20$ & 242 & 59.3 \\
\hline \multirow[t]{2}{*}{ Residence } & Urban & 253 & 62.0 \\
\hline & Rural & 155 & 38.0 \\
\hline \multirow{2}{*}{ Sex of the participants } & Male & 214 & 52.5 \\
\hline & Female & 194 & 47.5 \\
\hline \multirow[t]{2}{*}{ Marital status } & Single* & 360 & 88.2 \\
\hline & Married & 48 & 11.8 \\
\hline \multirow[t]{3}{*}{ Religion of the participants } & Orthodox & 207 & 50.7 \\
\hline & Muslim & 183 & 44.9 \\
\hline & Others + & 18 & 4.4 \\
\hline \multirow[t]{2}{*}{ Type of Education enrollment } & TVET (Diploma) & 215 & 52.7 \\
\hline & Degree (First) & 193 & 47.3 \\
\hline \multirow[t]{2}{*}{ Program } & Regular & 377 & 92.4 \\
\hline & Evening (Extension) & 31 & 7.6 \\
\hline \multirow[t]{3}{*}{ Field of Study } & Health related & 233 & 57.1 \\
\hline & Business related & 129 & 31.6 \\
\hline & Technology related & 46 & 11.3 \\
\hline \multirow[t]{4}{*}{ Academic year } & Year I & 151 & 37.0 \\
\hline & Year II & 180 & 44.1 \\
\hline & Year III & 58 & 14.2 \\
\hline & Year IV+ & 19 & 4.7 \\
\hline \multirow[t]{4}{*}{ Living with; } & Families & 340 & 83.3 \\
\hline & Relatives & 28 & 6.9 \\
\hline & Alone & 21 & 5.1 \\
\hline & Others ++ & 19 & 4.7 \\
\hline \multirow{2}{*}{$\begin{array}{l}\text { Total family size (including } \\
\text { extended families) }\end{array}$} & $<5$ & 198 & 48.5 \\
\hline & $5+$ & 210 & 51.5 \\
\hline \multirow[t]{3}{*}{ Monthly income (in ETB) } & $<1000$ & 349 & 85.5 \\
\hline & $1000-1500$ & 47 & 11.5 \\
\hline & $>1500$ & 12 & 2.9 \\
\hline
\end{tabular}

Key: Single* "currently not married", Others+ (Protestant, Catholic), Others ++ (friends, sister-in-law and son-in-laws)

Source of information about COVID-19: In this study, 293(71.8\%) of the students had information about COVID-19 from mass media (TV, magazines, news paper, radio) and nearly fifty percent $(54.2 \%)$ of the participants had information from social media (facebook, Instagram, whatsup and telegram) (Figure 1). 


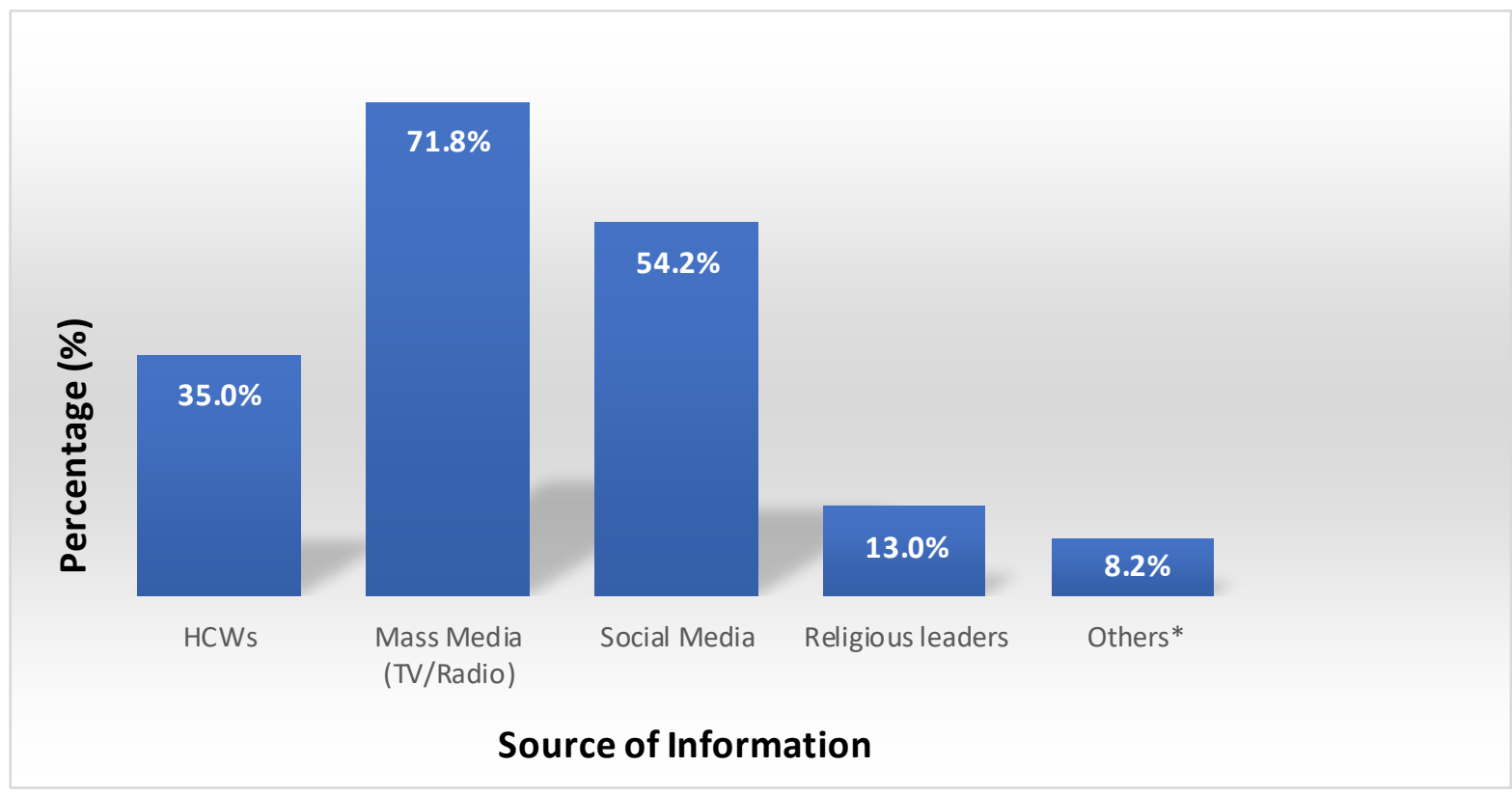

Figure 1: Source of information where college students acquired information regarding COVID-19 pandemic, June 2020, Ethiopia

Mode of Transmissions and sxymptoms of COVID-19: In this study, 276(67.6\%) of the students said that air droplets from the infected persons can transmit the infection of COVID-19 to healthy individuals. Similarly, 375(91.9\%), $343(84.1 \%)$, and $324(79.4 \%)$ of the participants said that patients with COVID-19 can present with fever, dry cough, and shortness of breath respectively (Figure 2). In this study, 338(82.8\%) of the students said that regular hand washing with water and soap can prevent COVID-19 pandemic. Similarly, 255(62.5\%) of the participants said that we can deter the transmission of COVID-19 by covering of mouth and nose while coughing or sneezing.

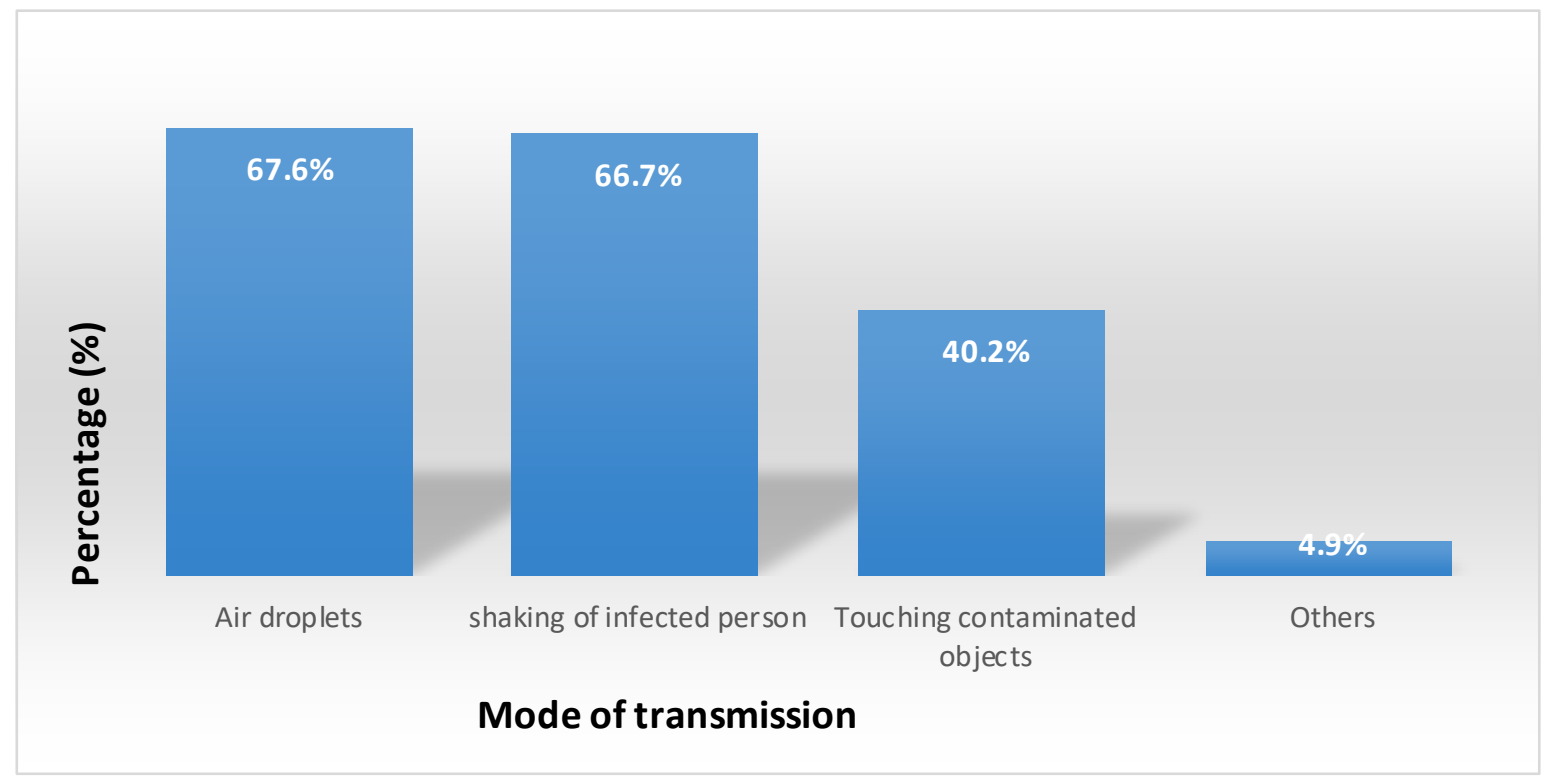

Figure 2: Students' knowledge on the mode of transmission of COVID-19, June 2020, Ethiopia 
Students knowledge level and its associated factors: In this study, 284(69.6\%) [95\% CI 65\% $74.3 \%$ ) of college students had good level of knowledge regarding COVID-19 pandemic. Selection of variables to be entered into multivariable logistic regression model was done based on clinical significance, predictor variables with p-value less than 0.25 in the bivariate logistic regression, and absence of multi-collinearity between independent variables. The selected covariates include age of respondents, residence, sex of participants, marital status, education enrollment type, study program, field of study, academic year, living conditions, and source of income for education were entered into the multivariable logistic regression analysis model. The multivariable logistic regression model was done with backward elimination methods.
In this study, the students who were in the age group (16-20 years) had twice higher odds of good knowledge level compared to those who were above 20 years old [AOR $=1.78,95 \%$ CI $1.07,2.69]$. Students who were living within more than five family members had $56 \%$ less likely to be knowledgeable about COVID-19 pandemic compared to those living within small family sizes $[\mathrm{AOR}=0.44: \quad 95 \%$ CI 0.28, 0.68]. Moreover, students who were single had 2.3 times greater odds of good knowledge compared to married students $\quad[\mathrm{AOR}=2.30: \quad 95 \%$ CI $1.09, \quad 5.55]$. However, residence, sex of participants, education enrollment type, study program, field of study, academic year, living conditions, and source of income for education were not found significantly associated with knowledge level of students towards COVID-19 pandemic (Table 2).

Table 2: Factors associated with knowledge level of students, Amhara Region, Ethiopia, 2020.

\begin{tabular}{llcccc}
\hline \multirow{2}{*}{ List of variable } & Category of & \multicolumn{2}{c}{ Knowledge levels } & COR (95\% CI) & AOR (95\% CI) \\
\cline { 2 - 4 } & variables & Good (\%) & Poor (\%) & & \\
\hline Age category & $16-20$ & $126(44.4)$ & $40(32.3)$ & $1.67(1.07,2.61)$ & $1.78(1.07,2.69)^{*}$ \\
(in years) & > & $158(55.6)$ & $84(67.7)$ & 1.00 & 1.00 \\
Residence & Urban & $182(64.1)$ & $71(57.3)$ & $1.33(0.86,2.05)$ & $1.24(0.77,1.99)$ \\
& Rural & $102(35.9)$ & $53(42.7)$ & 1.00 & 1.00 \\
Sex of participants & Females & $154(54.2)$ & $60(48.4)$ & $1.26(0.82,1.93)$ & $1.18(0.74,1.89)$ \\
& Males & $130(45.8)$ & $64(51.6)$ & 1.00 & 1.00 \\
Marital status & Single & $253(89.1)$ & $107(86.3)$ & $0.77(0.41,1.45)$ & $2.30(1.09,5.55)^{*}$ \\
& Married & $31(10.9)$ & $17(13.7)$ & 1.00 & 1.00 \\
Education & Diploma (TVET) & $146(51.4)$ & $69(55.6)$ & $0.84(0.55,1.29)$ & $0.64(0.36,1.12)$ \\
enrollment type & Degree (first) & $138(48.6)$ & $55(44.4)$ & 1.00 & 1.00 \\
Program & Regular & $263(92.6)$ & $114(91.9)$ & $0.91(0.41,1.99)$ & $1.65(0.61,4.48)$ \\
& Extension & $21(7.4)$ & $10(8.1)$ & 1.00 & 1.00 \\
Field of study & Health related & $160(56.3)$ & $73(58.9)$ & 1.00 & 1.00 \\
& Business & $86(30.3)$ & $43(34.7)$ & $0.91(0.57,1.44)$ & $0.71(0.38,1.32)$ \\
\multirow{2}{*}{ Academic year } & Technology & $38(13.4)$ & $8(6.5)$ & $2.17(0.96,4.87)$ & $2.60(0.93,7.25)$ \\
& Year I & $107(37.7)$ & $44(35.5)$ & $1.12(0.40,3.14)$ & $1.87(0.54,6.46)$ \\
& Year II & $123(43.3)$ & $57(46.0)$ & $0.99(0.36,2.75)$ & $2.05(0.58,7.18)$ \\
& Year III & $41(14.4)$ & $17(13.7)$ & $1.11(0.36,3.41)$ & $2.46(0.64,9.43)$ \\
Family size & Year IV+ & $13(4.6)$ & $6(4.8)$ & 1.00 & 1.00 \\
& $<5$ & $121(42.6)$ & $77(62.1)$ & $0.45(0.29,0.69)$ & $0.44(0.28,0.68)^{*}$ \\
Living with; & F+ & $163(57.4)$ & $47(37.9)$ & 1.00 & 1.00 \\
& Family & $234(82.4)$ & $106(85.5)$ & 1.00 & 1.00 \\
& Relatives & $19(6.7)$ & $9(7.3)$ & $0.97(0.42,2.18)$ & $0.63(0.24,1,67)$ \\
& Alone & $15(5.3)$ & $6(4.8)$ & $1.13(90.43,3.00)$ & $1.16(0.34,3.910$ \\
Monthly income for & Others+ & $16(5.6)$ & $3(2.4)$ & $2.42(0.69,8.47)$ & $3.32(0.79,13,95)$ \\
education (in ETB) & $<1000$ & $237(83.5)$ & $112(90.3)$ & 1.00 & 1.00 \\
& $1000-1500$ & $39(13.7)$ & $8(6.5)$ & $2.30(1.04,5.09)$ & $3.08(1.36,6.95)^{*}$ \\
& $>1500$ & $8(2.8)$ & $4(3.2)$ & $0.94(0.28,3.21)$ & $1.27(0.36,4.41)$ \\
\hline
\end{tabular}

Key: COR- Crude Odds Ratio, AOR- Adjusted Odds Ratio, * - P-value $<0.05$, Others+: friends, sister-in-law and sonin-laws 
Students attitude towards COVID-19 and associated factors: This study revealed that $230(56.4 \%)$ [95\% CI $51.2 \%, 61 \%$ ] of college students had positive attitude towards the prevention and control strategies of COVID-19 pandemic.

The multivariable logistic regression model was done with backward elimination methods. In this study, the odds of positive attitude among single students was 3-folds higher compared to married students [AOR=2.78, 95\% CI 1.15, 6.68]. Students who were attending diploma (TVET) level trainings were $73 \%$ less likely to have positive attitudes towards COVID-19 prevention and control measures compared to those who were attending degree program trainings $[\mathrm{AOR}=0.27$ : 95\% CI 0.17, 0.42]. Moreover, year-two students had 4-folds greater odds of positive attitude compared to year-four and above students [AOR=4.44: 95\% CI 1.55, 12.68]. However, age of participants, residence, sex of participants, study program, field of study, living conditions, source of income for education, and knowledge level were not significantly associated with attitude level of students towards COVID-19 pandemic prevention measures (Table 3 ).

Table 3: Factors associated practice level of students in Amhara region, Ethiopia, 2020.

\begin{tabular}{|c|c|c|c|c|c|}
\hline \multirow[t]{2}{*}{ List of variable } & \multirow{2}{*}{$\begin{array}{l}\text { Category of } \\
\text { variables }\end{array}$} & \multicolumn{2}{|c|}{ Practice levels } & \multirow[t]{2}{*}{ COR (95\% CI) } & \multirow[t]{2}{*}{ AOR (95\% CI) } \\
\hline & & Good (\%) & Poor (\%) & & \\
\hline \multirow{2}{*}{$\begin{array}{l}\text { Age category } \\
\text { (in years) }\end{array}$} & $16-20$ & $102(38.5)$ & $64(44.8)$ & $0.77(0.51,1.16)$ & $1.06(0.63,1.76)$ \\
\hline & $>20$ years & $163(61.5)$ & $79(55.2)$ & 1.00 & 1.00 \\
\hline \multirow[t]{2}{*}{ Residence } & Urban & $189(71.3)$ & $64(44.8)$ & $3.07(2.01,4.68)$ & $2.89(1.85,4.53)^{*}$ \\
\hline & Rural & $76(28.7)$ & $79(55.2)$ & 1.00 & 1.00 \\
\hline \multirow[t]{2}{*}{ Sex of participants } & Females & $145(54.7)$ & $69(48.3)$ & $1.29(0.86,1.94)$ & $1.15(0.71,1.85)$ \\
\hline & Males & $120(45.3)$ & $74(51.7)$ & 1.00 & 1.00 \\
\hline \multirow[t]{2}{*}{ Marital status } & Single & $227(85.7)$ & $133(93.0)$ & $0.45(0.22,0.93)$ & $0.86(0.32,2.27)$ \\
\hline & Married & $38(14.3)$ & $10(7.0)$ & 1.00 & 1.00 \\
\hline \multirow{2}{*}{$\begin{array}{l}\text { Education } \\
\text { enrollment type }\end{array}$} & Diploma (TVET) & $131(49.4)$ & $84(58.7)$ & $0.68(0.45,1.03)$ & $0.81(0.45,1.43)$ \\
\hline & Degree (first) & $134(50.6)$ & $59(41.3)$ & 1.00 & 1.00 \\
\hline \multirow[t]{2}{*}{ Program } & Regular & $238(89.8)$ & $139(97.2)$ & $0.25(0.18,0.74)$ & $0.26(0.18,0.81)^{*}$ \\
\hline & Extension & $27(10.2)$ & $4(2.8)$ & 1.00 & 1.00 \\
\hline \multirow[t]{3}{*}{ Field of study } & Health related & $146(55.1)$ & $87(60.8)$ & 1.00 & 1.00 \\
\hline & Business & $85(32.1)$ & $44(30.8)$ & $1.15(0.73,1.81)$ & $0.71(0.38,1,33)$ \\
\hline & Technology & $34(12.8)$ & $12(8.4)$ & $1.68(0.83,3.43)$ & $0.63(0.25,1.53)$ \\
\hline \multirow[t]{4}{*}{ Academic year } & Year I & $85(32.1)$ & $66(46.2)$ & $0.15(0.12,0.67)$ & $0.17(0.14,0.82)^{*}$ \\
\hline & Year II & $113(42.6$ & $67(46.9)$ & $0.19(0.14,0.88)$ & $0.22(0.14,1.05)$ \\
\hline & Year III & $50(18.9)$ & $8(5.6)$ & $0.73(0.14,3.81)$ & $0.84(0.15,4.52)$ \\
\hline & Year IV+ & $17(6.4)$ & $2(1.4)$ & 1.00 & 1.00 \\
\hline \multirow[t]{2}{*}{ Family size } & $<5$ & $126(47.5)$ & $72(50.3)$ & $0.89(0.59,1.34)$ & $0.72(0.45,1.17)$ \\
\hline & $5+$ & $139(52.5)$ & $71(49.7)$ & 1.00 & 1.00 \\
\hline \multirow[t]{3}{*}{ Living with; } & Family & $207(78.1)$ & 133(93.0) & 1.00 & 1.00 \\
\hline & Relatives & $24(9.1)$ & $4(2.8)$ & $3.85(1.31,11.36)$ & $3.50(1.13,10.83)^{*}$ \\
\hline & Others + & $34(12.8)$ & $6(4.2)$ & $3.64(0.89,8.29)$ & $1.42(0.44,4.57)$ \\
\hline \multirow{3}{*}{$\begin{array}{l}\text { Monthly income for } \\
\text { education (in ETB) }\end{array}$} & $<1000$ & $219(82.6)$ & $130(90.9)$ & 1.00 & 1.00 \\
\hline & $1000-1500$ & $38(14.3)$ & $9(6.3)$ & $2.51(1.17,5.35)$ & $1.21(0.44,3.31)$ \\
\hline & $>1500$ & $8(3.0)$ & $4(2.8)$ & $1.18(0.35,4.02)$ & $0.44(0.19,2.16)$ \\
\hline \multirow[t]{2}{*}{ Knowledge level } & poor & $78(29.4)$ & $46(32.2)$ & $0.88(0.57,1.36)$ & $1.04(0.62,1.74)$ \\
\hline & Good & $187(70.6)$ & $97(67.8)$ & 1.00 & 1.00 \\
\hline \multirow[t]{2}{*}{ Attitude towards } & Negative & $113(42.6)$ & $65(45.5)$ & $0.89(0.59,1.34)$ & $0.89(0.54,1.49)$ \\
\hline & Positive & $152(57.4$ & $78(54.5)$ & 1.00 & 1.00 \\
\hline
\end{tabular}

Key: COR- Crude Odds Ratio, AOR- Adjusted Odds Ratio, * - P-value $<0.05$, Others ${ }^{+}$(friends, alone, sister/son-inlaws) 
Students practice level towards COVID-19 and associated factors: This study revealed that $265(6 \%)$ [95\% CI $60,70.1 \%$ ] of college students had good level of prevention practice regarding COVID-19 pandemic.

In this study, the students who were living in urban residence had 3-times greater odds of good practice level towards COVID-19 prevention and control measures compared to those who were living in rural residence during the pandemic [AOR $=2.89,95 \%$ CI 1.85, 4.53]. Regular program students were $74 \%$ less likely to have good practice on the prevention and control measures compared to extension (evening) program students $[\mathrm{AOR}=0.26: 95 \% \mathrm{CI} 0.18,0.81]$. Finally, year-one students had $83 \%$ less likely good practice on the prevention and control measures compared to year-four students $[\mathrm{AOR}=0.17$ : 95\% CI 0.14 , 0.82]. However, residence, sex of participants, education enrollment type, field of study, living conditions, source of income for education, knowledge level and attitude towards COVID-19 prevention and control measures were not significantly associated with knowledge level of students towards COVID-19 pandemic (Table 4).

Table 4: Factors associated with attitude of students towards COVID-19.

\begin{tabular}{|c|c|c|c|c|c|}
\hline \multirow[t]{2}{*}{ List of variable } & \multirow{2}{*}{$\begin{array}{l}\text { Category of } \\
\text { variables }\end{array}$} & \multicolumn{2}{|c|}{ Attitude level } & \multirow[t]{2}{*}{ COR $(95 \%$ CI) } & \multirow[t]{2}{*}{ AOR (95\% CI) } \\
\hline & & $\begin{array}{l}\text { Positive } \\
\text { (\%) }\end{array}$ & $\begin{array}{l}\text { Negative } \\
(\%)\end{array}$ & & \\
\hline \multirow{4}{*}{$\begin{array}{l}\text { Age category } \\
\text { (in years) } \\
\text { Residence }\end{array}$} & $16-20$ & $87(37.8)$ & $79(44.4)$ & $0.76(0.51,1.13)$ & $0.62(0.37,1.03)$ \\
\hline & $>20$ years & $143(62.2)$ & $99(55.6)$ & 1.00 & 1.00 \\
\hline & Urban & $150(65.2)$ & $103(57.9)$ & $1.36(0.91,2.04)$ & $1.15(0.71,1.85)$ \\
\hline & Rural & $80(34.8)$ & $75(42.1)$ & 1.00 & 1.00 \\
\hline \multirow[t]{2}{*}{ Sex of participants } & Females & $124(53.9)$ & $90(50.6)$ & $1.14(0.77,1.69)$ & $1.37(0.85,2.20)$ \\
\hline & Males & $106(46.1)$ & $88(49.4)$ & 1.00 & 1.00 \\
\hline \multirow[t]{2}{*}{ Marital status } & Single & $208(90.4)$ & $152(85.4)$ & $1.62(0.88,2.96)$ & $2.78(1.15,6.68)^{*}$ \\
\hline & Married & $22(9.6)$ & $26(14.6)$ & 1.00 & 1.00 \\
\hline \multirow{4}{*}{$\begin{array}{l}\text { Education } \\
\text { enrollment type } \\
\text { Program }\end{array}$} & Diploma (TVET) & $93(40.4)$ & $122(68.5)$ & $0.31(.21,0.47)$ & $0.27(0.17,0.42)^{*}$ \\
\hline & Degree (first) & $137(59.6)$ & $56(31.5)$ & 1.00 & 1.00 \\
\hline & Regular & $214(93.0)$ & $163(91.6)$ & $1.23(0.59,2.56)$ & $1.26(0.48,3.27)$ \\
\hline & Extension & $16(7.0)$ & $15(8.4)$ & 1.00 & 1.00 \\
\hline \multirow[t]{3}{*}{ Field of study } & Health related & $110(47.8)$ & $123(69.1)$ & 1.00 & 1.00 \\
\hline & Business & $91(39.6)$ & $38(21.3)$ & $2.67(1,69,4.23)$ & $1.58(0.85,2.94)$ \\
\hline & Technology & $29(12.6)$ & 17(9.6) & $1.91(0.99,3.66)$ & $2.26(0.95,5.41)$ \\
\hline \multirow[t]{4}{*}{ Academic year } & Year I & $73(31.7)$ & $78(43.8$ & $1.29(0.49,3.38)$ & $2.18(0.76,63)$ \\
\hline & Year II & $118(51.3)$ & $62(34.8)$ & $2.62(1.01,6.84)$ & $4.44(1.55,12.68)^{*}$ \\
\hline & Year III & $31(13.5)$ & $27(15.2)$ & $1.58(0.55,4.49)$ & $1.77(0.57,5.44)$ \\
\hline & Year IV+ & $8(3.5)$ & $11(6.2)$ & 1.00 & 1.00 \\
\hline \multirow[t]{2}{*}{ Family size } & $<5$ & $114(49.6)$ & $84(47.2)$ & $1.11(0.74,1.62)$ & $1.46(0.91,2.34)$ \\
\hline & $5+$ & $116(50.4)$ & $94(52.8)$ & 1.00 & 1.00 \\
\hline \multirow[t]{4}{*}{ Living with; } & Family & $194(84.3)$ & $146(82.0)$ & 1.00 & 1.00 \\
\hline & Relatives & $14(6.1)$ & $14(7.9)$ & $0.75(0.35,1.63)$ & $0.47(0.18,1.22)$ \\
\hline & Alone & $11(4.8)$ & $10(5.6)$ & $0.83(0.34,2.01)$ & $0.67(0.22,2.04)$ \\
\hline & Others+ & $11(4.8)$ & $8(4.5)$ & $1.03(0.41,2.64)$ & $0.84(0.27,2.66)$ \\
\hline \multirow{3}{*}{$\begin{array}{l}\text { Monthly income for } \\
\text { education (in ETB) }\end{array}$} & $<1000$ & $195(84.8)$ & $154(86.5)$ & 1.00 & 1.00 \\
\hline & $1000-1500$ & $30(13.0)$ & $17(9.6)$ & $1.39(0.74,2.62)$ & $2.22(0.93,5.26)$ \\
\hline & $>1500$ & $5(2.2)$ & $7(3.9)$ & $0.56(0.18,1.81)$ & $0.78(0.19,3.14)$ \\
\hline \multirow[t]{2}{*}{ Knowledge } & Poor & $47(20.4)$ & $7743.3)$ & $0.34(0.22,0.52)$ & $0.31(0.19,0.48)^{*}$ \\
\hline & Good & 183(79.6) & $101(56.7)$ & 1.00 & 1.00 \\
\hline
\end{tabular}

Key: COR- Crude Odds Ratio, AOR- Adjusted Odds Ratio, * - P-value $<0.05$, Others + : friends, sister-in-law and sonin-laws.

\section{DISCUSSION}


The study found that the overall level of knowledge regarding COVID-19 pandemic among college students was $69.6 \%$ [95\% CI 65\% $74.3 \%$ ). This finding is lower than studies conducted among Indian medical students (94.5\%) (27), eight countries of five continents (80.8\%) determinants (28), Malaysia (80.5\%) (29), Sudan (90.6\%) (30), and Pakistan (71.5\%) (20). The discrepancy might be due to differences in cut-values used to categorize the knowledge levels, sample size, and sociocultural variables between study settings. However, this result is higher than a study conducted in Syrian residents (60\%) (31), USA (58\%) (32), Bangladesh (48.3\%) (57.6\%) (10\%) $(17,33,34)$, three Middle East countries (66.1\%) (35), Makerere University Teaching Hospital (66\%) (18), and Pakistan $(51.8 \%)$ (36). The differences in level of knowledge have been subjected to variation in the cut-values (i.e. most of the previous studies used more than $80 \%$ to say good knowledge) while this study used $70 \%$ to categorized study participants with good level of knowledge. In addition, the discrepancies might be due to differences in sample size and study settings.

This study revealed that students in the late adolescent age group (i.e. 16-20 years) were twice more knowledgeable regarding COVID-19 compared to those who were above 20 years old. This finding is similar to a study done in Kingdom of Saudi Arabia (37), China (25), Medical college students in Uttarakhand, and India (24). Adolescents are very eager to know emerging new events including the new novel virus (COVID-19) than adults (38). Hence, students in the late age group are more knowledgeable compared to adults.

This study showed that students living with less than five family members had $56 \%$ less likely to have good knowledge of COVID-19 pandemic than to those living within small family sizes. This finding is consistent with a study conducted in Tanzania (39). This could be justified by the fact that students from small family size may spend most of their time by watching movies than families with large members who are obligated to have common source of information that will help the whole family members. Thus, these people are more likely to get the information disseminated by the government compared to their counterparts.
The finding of this study indicated that single students had 2.3 times greater odds of good knowledge compared to married students. This finding is supported by a study conducted in eight countries to assess knowledge level and its sociodemographic determinants (28). Hence, single students may have sufficient time (23) to acquire adequate information regarding COVID19 compared to married individuals who may be busy in the care of the families.

This study revealed that $56.4 \%$ [95\% CI $51.2 \%, 61 \%$ ] of study participants had a positive attitude towards the prevention and control measures of COVID-19 pandemic. This finding is lower than studies conducted among Indian medical students (93.7\%) (27), Syrian residents (63.5\%) (31), Malaysian residents (83.1\%) (29), Bangladesh (62.3\%) (17), Sudan (81.8\%) (30), 10 universities in Shaanxi Province, China $(73.8 \%)$ (40), Uganda (72.4\%) (41), and India (97.3\%). However, this result is higher than the studies conducted in Pakistan (44\%) (20), and Makerere University Teaching Hospital (21\%) (18). The discrepancy may be subjected to variation in the cut-values to measure the positive and negative attitude levels. Besides, the discrepancies might be due to differences in sample size and study settings.

In this study, the odds of positive attitude among single students was 3-folds higher compared to married students. This finding is consistent with a study conducted in eight countries of five continents (28). Consequently, single students might have adequate time (23) to listen and search relevant information regarding COVID 19. Thus, single students could have positive attitude towards COVID-19 compared to married individuals who have busy time taking care of the families.

This study revealed that students who were attending diploma (TVET) level training were $73 \%$ less likely to have positive attitudes towards COVID-19 preventive measures compared to those who were attending degree program training. Moreover, year-two students had 4-folds greater odds of positive attitude compared to year-four and above students. When the education level of students increases, their attitude towards the preventive measures will increase. This is supported by the study conducted among Indonesian undergraduate students (42). Thus, students with degree level training could have a 
higher attitude towards the preventive measures of COVID-19 than students attending lower level training.

This study revealed that $65 \%$ [95\% CI 60, $70.1 \%$ ] of college students had a good level practice towards the prevention measures of COVID-19 pandemic. This finding is lower than a study done in Syria (73.8\%) (31), Pakistan (80.5\%) (36), Sudan (89.9\%) (30), students in 10 universities in Shaanxi Province, China (87.9\%) (40), and Uganda (85.3\%) (41). However, this finding is higher than studies conducted in Bangladesh (55.1\%) (17), and Pakistan (57.3\%) (20). The differences in the practice of preventive measures could have been subjected to variation in the cut-off values to classify good or poor practice. For instance, most of the previous studies used above $80 \%$ scores to determine adequate practice while the current study used $70 \%$ and above to categorize study participants to good level of practice. In addition, the discrepancies might be due to differences in sample size and study settings.

This study indicated that students who were living in urban residence had 3-times greater odds of good practice level towards COVID-19 prevention and control measures compared to those who were living in rural residence during the pandemic. This finding is similar to studies conducted among Indonesian undergraduate students (42), Sudan (30), and Nepalese residents.

Moreover, this study revealed that regular program students were $74 \%$ less likely to have a good practice on the prevention and control measures compared to extension (evening) program students. Similarly, year-one students had $83 \%$ less likely good practice on the prevention and control measures compared to year-four students. This finding is similar to studies conducted among Indonesian undergraduate students (42). Therefore, when the year of study increases the level of practice also increases. Hence, year four students have a greater practice of preventive measures of COVID-19 compared to year-one students.

This study was done using a phone-call interview which may be prone to social desirability bias. Besides, the study did not involved adolescents in high schools and precollege schools. Thus, it may not represent all of the adolescents in Dessie town. Moreover, the study also shares the limitations of a crosssectional study design.

In conclusion, the overall students' KAP level towards COVID-19 was not comparable to the WHO recommended KAP scores for the general population, which is true of students.

After adjusting for covariates: being in the late adolescent age group, living with $>5$ family size, and being single were predictors of knowledge level.

This study revealed that being single, taking diploma (TVET) level trainings, and being yeartwo students were predictors of attitude levels. Finally, residence, being regular students, and academic year were the independent predictors of the practice level of students. Therefore, the authors have recommended that the Ministry of Science and Higher Education [MOSHE], regional education bureau, and local governments have to develop effective strategies and interventions to address the identified gaps of KAP and its associated factors among students that will have direct negative impact on the prevention and control activities to halt the spread of the outbreak. Besides, this finding will help the private and public college administration to reach their students since the summary of the results were disseminated to all included colleges and other stakeholders.

\section{ACKNOWLEDGEMENTS}

We would like to thank Dream Science and Technology College for its ethical approval. Furthermore, our deepest gratitude goes to the hospital staffs, participants, data collectors and supervisors.

\section{REFERENCES}

1. Wu D, Wu T, Liu Q, Yang Z. The SARSCoV-2 outbreak: what we know. International Journal of Infectious Diseases. 2020.

2. Wu Y, Ho W, Huang Y, Jin D-Y, Li S, Liu S$\mathrm{L}$, et al. SARS-CoV-2 is an appropriate name for the new coronavirus. The Lancet. 2020;395(10228):949-50.

3. Zhu N, Zhang D, Wang W, Li X, Yang B, Song $J$, et al. A novel coronavirus from patients with pneumonia in China, 2019. New England Journal of Medicine. 2020.

4. Lu H, Stratton CW, Tang YW. Outbreak of Pneumonia of Unknown Etiology in Wuhan 
China: the Mystery and the Miracle. Journal of Medical Virology. 2020.

5. WHO. Coronavirus disease (COVID-19) Situation Report - 131. Available: https://www.who.int/emergencies/diseases/no vel-coronavirus-2019/situation-reports-131. 2020.

6. EPHI-Ethiopia. Notification Note on COVID19 Situational Update:

https://www.ephi.gov.et/index.php/publichealth-emergency/novel-corona-virus-update, Accessed on May 20, 2020. 2020.

7. EPHI-Ethiopia. Notification Note on COVID19 Situational Update:

https://www.ephi.gov.et/index.php/publichealth-emergency/novel-corona-virus-update. June 2020.

8. Burke RM. Active monitoring of persons exposed to patients with confirmed COVID19-United States, January-February 2020. MMWR Morbidity and mortality weekly report. 2020;69.

9. Zettler I, Schild C, Lilleholt L, Böhm R. Individual differences in accepting personal restrictions to fight the COVID-19 pandemic: Results from a Danish adult sample. 2020.

10. Dong Y, Mo X, Hu Y, Qi X, Jiang F, Jiang Z, et al. Epidemiology of COVID-19 among children in China. Pediatrics. 2020.

11. $\mathrm{Hu} \mathrm{W}, \mathrm{Su}$ L, Qiao J, Zhu J, Zhou Y. Countrywide quarantine only mildly increased anxiety level during COVID-19 outbreak in China. medRxiv. 2020.

12. Wang C, Pan R, Wan X, Tan Y, Xu L, Ho CS, et al. Immediate psychological responses and associated factors during the initial stage of the 2019 coronavirus disease (COVID-19) epidemic among the general population in China. International journal of environmental research and public health. 2020;17(5):1729.

13. Liu S, Yang L, Zhang C, Xiang Y-T, Liu Z, $\mathrm{Hu} \mathrm{S}$, et al. Online mental health services in China during the COVID-19 outbreak. The Lancet Psychiatry. 2020;7(4):e17-e8.

14. Holmes EA, O'Connor RC, Perry VH, Tracey I, Wessely S, Arseneault L, et al. Multidisciplinary research priorities for the COVID-19 pandemic: a call for action for mental health science. The Lancet Psychiatry. 2020.

15. Li S, Wang Y, Xue J, Zhao N, Zhu T. The impact of COVID-19 epidemic declaration on psychological consequences: a study on active Weibo users. International journal of environmental research and public health. 2020;17(6):2032.

16. Jiang Y. Psychological impact and coping strategies of frontline medical staff in Hunan between January and March 2020 during the outbreak of Coronavirus Disease 2019 (COVID-19) in Hubei, China. Med Sci Monit. 2020;26:924171.

17. Ferdous MZ, Islam MS, Sikder MT, Mosaddek ASM, Zegarra-Valdivia J. Knowledge, attitude, and practice regarding COVID-19 outbreak in Bangladeshi people: An online-based cross-sectional study. medRxiv. 2020.

18. Olum R, Chekwech G, Wekha G, Nassozi DR, Bongomin F. Coronavirus Disease-2019: Knowledge, Attitude, and Practices of Health Care Workers at Makerere University Teaching Hospitals, Uganda. Frontiers in Public Health. 2020;8:181.

19. Zhang M, Zhou M, Tang F, Wang Y, Nie H, Zhang L, et al. Knowledge, attitude, and practice regarding COVID-19 among healthcare workers in Henan, China. Journal of Hospital Infection. 2020;105(2):183-7.

20. Muhammad K, Saqlain M, Hamdard A, Naveed M, Umer MF, Khan S, et al. Knowledge, attitude, and practices of Community pharmacists about COVID-19: A cross-sectional survey in two provinces of Pakistan. medRxiv. 2020.

21. FMOH. COVID 19 Handbook for health professionals Federal Minstry of Health, Ethiopia, Availabile: https://www.moh.gov.et. 2020.

22. FMOH. Infection Prevention and Control Interim Protocol for COVID-19 In Health Care Settings in Ethiopia. Availabile: https://www.moh.gov.et. Addis Ababa, Ethiopia: FMOH; 2020.

23. Zhong B-L, Luo W, Li H-M, Zhang Q-Q, Liu $\mathrm{X}-\mathrm{G}, \mathrm{Li} \mathrm{W}-\mathrm{T}$, et al. Knowledge, attitudes, and practices towards COVID-19 among Chinese residents during the rapid rise period of the COVID-19 outbreak: a quick online crosssectional survey. International journal of biological sciences. 2020;16(10):1745.

24. Maheshwari S, Gupta PK, Sinha R, Rawat P. Knowledge, attitude, and practice towards coronavirus disease 2019 (COVID-19) among 
medical students: A cross-sectional study. Journal of Acute Disease. 2020;9(3):100.

25. Lihua M, Ma L, Liu H, Jiang N, Wang S, Jiang $X$. Knowledge, beliefs/attitudes and practices of rural residents in the prevention and control of COVID-19: An online questionnaire survey. medRxiv. 2020.

26. FMOH. COVID 19 Handbook for health professionals Federal Minstry of Health, Ethiopia, Availabile: https://www.moh.gov.et. 2020.

27. Joshi K, Jamadar, Deepak. Knowledge, attitude and practices regarding COVID-19 among medical students-A cross sectional study. 2020.

28. Ali M, Uddin Z, Banik PC, Hegazy FA, Zaman S, Ambia ASM, et al. Knowledge, attitude, practice and fear of COVID-19: A cross-cultural study. medRxiv. 2020.

29. Azlan AA, Hamzah MR, Sern TJ, Ayub SH, Mohamad E. Public knowledge, attitudes and practices towards COVID-19: A crosssectional study in Malaysia. Plos one. 2020;15(5):e0233668.

30. Mohamed A, Elhassan E, Mohamed AO, Mohammed AA, Mahgoop MA, Sharif ME, et al. Knowledge, attitude and practice of the Sudanese people towards COVID-19: An online survey. medRxiv. 2020.

31. Al Ahdab S. Knowledge, Attitudes and Practices (KAP) towards pandemic COVID19 among Syrians. medRxiv. 2020.

32. Alobuia WM, Dalva-Baird NP, Forrester JD, Bendavid E, Bhattacharya J, Kebebew E. Racial disparities in knowledge, attitudes and practices related to COVID-19 in the USA. Journal of Public Health. 2020.

33. Karim A, Akter M, Mazid AT, Pulock OS, Aziz TT, Hayee S, et al. Knowledge and attitude towards COVID-19 in Bangladesh: Population-level estimation and a comparison. Nature. 2020;5(4):536-44.

34. Paul A, Sikdar D, Hossain MM, Amin MR, Deeba F, Mahanta J, et al. Knowledge, Attitude and Practice Towards Novel Corona Virus among Bangladeshi People:
Implications for mitigation measures. medRxiv. 2020.

35. Naser AY, Dahmash EZ, Alwafi H, Alsairafi ZK, Al Rajeh AM, Alhartani YJ, et al. Knowledge and practices towards COVID-19 during its outbreak: a multinational crosssectional study. medRxiv. 2020.

36. Saqlain M, Ahmed A, Gulzar A, Naz S, Munir MM, Ahmed Z, et al. Public Knowledge and Practices regarding COVID-19: A crosssectional survey from Pakistan. medRxiv. 2020.

37. Al-Hanawi M, Angawi K, Alshareef N, Qattan A, Helmy $\mathrm{H}$, Abudawood $\mathrm{Y}$, et al. Knowledge, Attitude and Practice Toward COVID-19 Among the Public in the Kingdom of Saudi Arabia: A Cross-Sectional Study. Front. Public health. 2020;8:217.

38. Nicholas T, Mandaah FV, Esemu SN, Vanessa ABT, Gilchrist KTD, Vanessa LF, et al. COVID-19 knowledge, attitudes and practices in a conflict affected area of the South West Region of Cameroon. The Pan African Medical Journal. 2020;35(34).

39. Byanaku A, Ibrahim M. Knowledge, attitudes, and practices (KAP) towards COVID-19: A quick online cross-sectional survey among Tanzanian residents. medRxiv. 2020.

40. Peng Y, Pei C, Zheng Y, Wang J, Zhang K, Zheng $Z$, et al. Knowledge, attitude and practice associated with COVID-19 among university students: a crosssectional survey in China. medRxiv. 2020.

41. Ssebuufu R, Sikakulya F, Binezero SM, Wasingya L, Nganza SK, Ibrahim B, et al. Awareness, knowledge, attitude and practice towards measures for prevention of the spread of COVID-19 in the Ugandans: A nationwide online cross-sectional Survey. medRxiv. 2020.

42. Saefi M, Fauzi A, Kristiana E, Adi WC, Muchson M, Setiawan ME, et al. Survey data of COVID-19-related Knowledge, Attitude, and Practices among Indonesian Undergraduate Students. Data in Brief. 2020:105855. 